\title{
THE INFLUENCE OF COMPANY CHARACTERISTICS ON CORPORATE SOCIAL RESPONSIBILITY DISCLOSURE IN MANUFACTURING COMPANIES LISTED ON THE IDX
}

\author{
Sukmawati Safitri Dewi, Gatot Prabowo dan Marhendra Wicaksono \\ STIESIA Surabaya, Universitas 45 Surabaya dan Universitas Surabaya \\ Email: sukmadewy91@gmail.com, gatot.prabowoo@gmail.com dan \\ gatot.prabowoo@gmail.com
}

\begin{abstract}
A manufacturing company is one company that has a large enough impact on the problem of pollution, as well as the waste that will be generated from the company's operating activities. This study aims to analyze the effect of company characteristics on disclosure of corporate social responsibility in manufacturing companies listed on the IDX. The characteristics of the company consist of size, profitability, leverage, management ownership, and board size. The sampling technique used in this study uses the purposive sampling method in manufacturing companies listed on the IDX listed in ICMD and listed on the IDX website in 2009-2011. consecutive. Of the 143 manufacturing companies listed on the IDX, only 34 companies met the predetermined criteria for the research sample. The data analysis technique was carried out by using the classical assumption test. Hypothesis testing uses multiple linear regression analysis and statistical analysis in the form of $F$ statistical tests and $t$ statistical tests with the help of SPSS 16.0 for windows. The results showed that simultaneously the variable size, leverage profitability, management ownership, and the size of the board of commissioners had an effect on the Corporate Social Responsibility Disclosure (CSRD). Partially, size, management ownership, and board size have an effect on Corporate Social Responsibility Disclosure (CSRD), while profitability and leverage have no effect on Corporate Social Responsibility Disclosure (CSRD).
\end{abstract}

Keywords: Size; profitability; leverage; management ownership; board size; Corporate Social Responsibility Disclosure (CSRD)

Coresponden Author

Email: sukmadewy91@gmail.com Artikel dengan akses terbuka dibawah lisensi

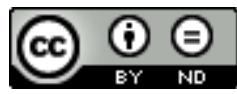

\section{Introduction}

Companies will get many positive impacts if CSR practices and disclosures are carried out continuously by the company itself. However, the Financial Accounting Standards in Indonesia have not yet obliged companies to disclose social information, 
especially information on corporate responsibility towards the environment, as a result, which often occurs in company practices only to disclose it voluntarily.

CSR is a form of action that departs from corporate ethical considerations directed at improving the economy accompanied by improving the quality of life of employees and their families, as well as improving the quality of life of the surrounding community and society at large (Hadi, 2011). CSR is a natural mechanism for a company to 'clean' the big profits it has (Prastowo, 2011).

In taking action to make corporate investment decisions, investors often see the size of a company which will then be assessed from the company's financial performance. Large companies usually have increasingly complex activities, have a greater impact on society, have more shareholders, and get more attention from the public, therefore large companies are under greater pressure to disclose their social responsibilities (Clough et al., 2011). (Dewi, Ida Ayu Putu Oki Yacintya; Yasa, 2018) suggest that company size is a scale where the size of the company can be classified as measured by total assets, total sales, share value and so on.

Profitability is one of the measuring tools used by companies in assessing the effectiveness of a company's performance. According to (Kasmir, 2016), profitability is a ratio to assess a company's ability to seek profit. This profitability provides an overview of how effectively the company operates so that it provides benefits for the company in seeking profit. According to (Hery, 2016) the profitability ratio is a ratio used to measure a company's ability to generate profits from its normal business activities. The profitability ratio is also known as the profitability ratio. (Fahmi, 2015) adds that this ratio measures the effectiveness of management as a whole which is aimed at the size of the level of profits obtained in relation to sales and investment.

Leverage is a ratio that describes the relationship between the company's debt to capital, where this ratio can see the extent to which the company is financed by debt or outsiders with the company's capabilities described by capital (Sofyan, 2013). According to (Mardiah, Satriana, \& Syahriati, 2017) leverage is the use of assets and sources of funds by companies that have fixed costs (fixed expenses), meaning that the source of funds comes from loans because they have interest as a fixed expense in order to increase the potential profit of shareholders.

Ownership structure is the separation between company owners and company managers. Owners or shareholders are parties who enter capital in the company, while managers are those appointed by the owner and given the authority to make decisions in managing the company, with the hope that managers act in accordance with the interests of the owners (Sudana, 2011).

(Zulhaimi \& Nuraprianti, 2019) profitability has a significant effect on CSR disclosure. Profitability does not have a significant effect on CSR disclosure. ((Respati \& Hadiprajitno, 2015). (Wilangga, Saebani, \& Wijayanti, 2020) shows that leverage has a significant effect on CSR disclosure. (Octarina, Majidah, \& Muslih, 2018) stated that leverage has no effect on CSR disclosure. The results of (Njoku, Agashi, \& Onyegegbu, 2017) state that managerial ownership has a positive and significant effect on CSR 
disclosure, meaning that the higher the number of managerial ownership, the higher the company's motivation in carrying out CSR disclosures. The size of the board of commissioners and the structure of foreign ownership have a significant positive effect on CSR disclosure (Laksmitaningrum \& Purwanto, 2013). The size of the board of commissioners and the structure of foreign ownership do not have a significant positive effect on CSR disclosure (Wulandari \& Sudana, 2018).

\section{Metod}

The type of research used in this research is quantitative research, namely research whose analysis generally uses data measured in a numerical scale (numbers) which is tested using statistical analysis. Secondary data is a source of research data obtained by researchers indirectly and using intermediary media. Meanwhile, according to the characteristics of the problem, this research is included in descriptive research, namely research whose activities are to conclude large amounts of raw data so that the results can be interpreted briefly and meaningfully. The purpose of descriptive research is to test the hypothesis of the subject under study.

\section{Results and Discussion}

1. Descriptive Statistical Analysis

Descriptive statistical analysis serves to provide an overview or description of data based on the mean, standard deviation, maximum and minimum values of each research variable. Descriptive statistics in this study are used to provide information about research variables such as the CSR disclosure index, size, profitability, leverage, management ownership, and the size of the board of commissioners.

2. Classic Assumption Test

a. Normality Test

On the histogram graph, a normal curve line is obtained, meaning that the data studied above is normally distributed. Likewise, the normal probability plot above is normally distributed because (the dots) spread out in the direction of the diagonal line. By paying attention to the graph, it can be said that the regression model fulfills the assumption of normality, so it is suitable for use.

Dependent Variable: CSRD

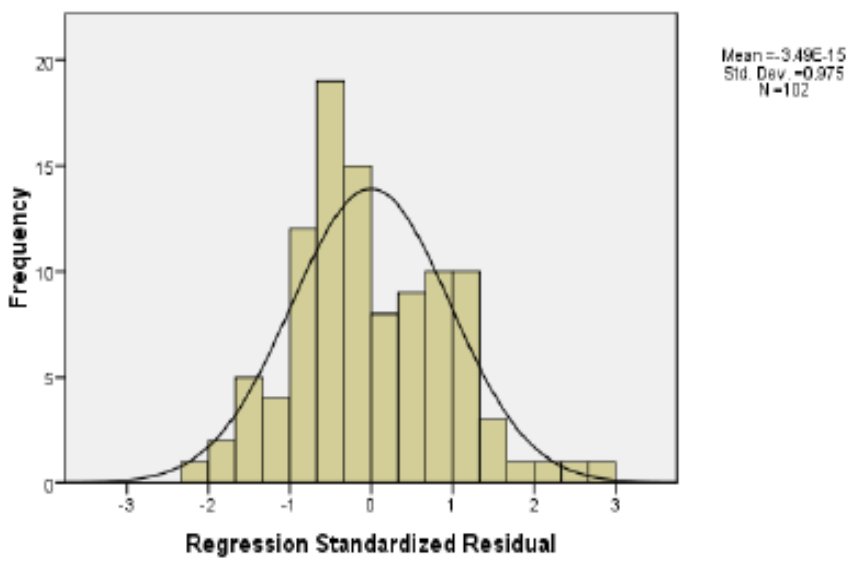


b. Multicollinearity Test

A good regression model should not have a correlation between the independent variables. If the independent variables are correlated, these variables are not orthogonal. Orthogonal variables are independent variables in which the correlation value between independent variables is equal to zero.

The multicollinearity test results above show that there are no independent variables (size, profitability, leverage, management ownership and size of the board of commissioners) which have a tolerance value less than 0.10 . The results of the vif value calculation also show the same results, there is no one independent variable that has a vif value of more than 10 . Therefore it can be concluded that there is no multicolation between the variables in the regression model.

c. Autocorrelation Test

A good regression equation is one that does not have autocorrelation problems. If autocorrelation occurs, the equation is not suitable for prediction. The autocorrelation problem only arises if there is a linear correlation between the confounding error of period $t$ (being) and the confounding error of period $t-1$ (previous).

Table 1 Auocorrelation test

\begin{tabular}{cccccc}
\hline Model & $\mathrm{R}$ & R Square & $\begin{array}{c}\text { Adjusted R } \\
\text { Square }\end{array}$ & $\begin{array}{c}\text { Std. Error of } \\
\text { the Estimate }\end{array}$ & $\begin{array}{c}\text { Durbin- } \\
\text { Watson }\end{array}$ \\
\hline 1 & 0,517 & 0,267 & 0,229 & 0,0901432 & 0,849 \\
\hline
\end{tabular}

a. Predictors: (Constant), KOM, LEV, PROF, MANJ, SIZE

b. Dependent Variable: CSRD

To determine whether there is autocorrelation with the durbi-watson (dw) test. From the results of the data processing above, it was found that the durbin watson test $=0.849$. This value is between $-2 \leq 0.849 \leq+2$. So it is concluded that the above data does not occur autocorrelation.

d. Heteroscedasticity Test

The heteroscedasticity test aims to test whether the residual variance occurs in the regression model from one observation to another. If the residual variable from one observation to another is constant, it is called homoscedasticity and if it is different, it is called heteroscedasticity. 


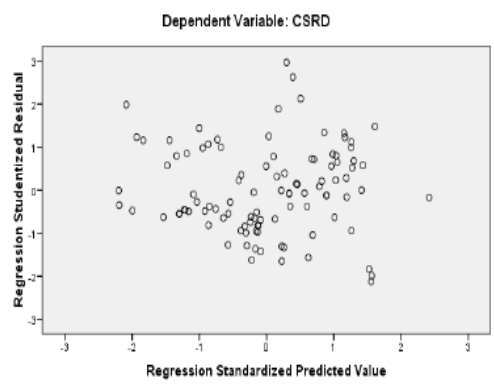

Figure 2. Heteroscedasticity test

Based on the graphical heteroscedasticity test, it is known that the dots are spread randomly and are spread either above or below the number 0 on the $y$ axis. It can be concluded that there is no heteroscedasticity symptom in the regression model.

\section{Multiple Linear Regression Analysis}

Regression analysis is an analysis that aims to determine the effect of a variable on other variables. In regression analysis, the variable that affects is called the independent variable (independent variable) and the variable that is affected is called the dependent variable (dependent variable).

Table 2

Multiple regression analysis

\begin{tabular}{|c|c|c|c|c|c|}
\hline No. & $\begin{array}{c}\text { Variabel } \\
\text { Bebas }\end{array}$ & $\begin{array}{l}\text { Koef. } \\
\text { Regresi }\end{array}$ & $\begin{array}{c}\mathrm{T} \\
\text { hitung }\end{array}$ & Sig. & $\mathrm{R}=0,517$ \\
\hline 1 & $\begin{array}{l}\text { Konstanta } \\
(\alpha)\end{array}$ & $-0,567$ & $-3,125$ & 0,002 & $\begin{array}{c}\mathrm{R}^{2}=0,267 \\
\text { Adjusted } \mathrm{R} \text { square }=0,229\end{array}$ \\
\hline 2 & $\operatorname{SIZA}\left(\mathrm{X}_{1}\right)$ & 0,072 & 4,500 & 0,000 & Std. Error of the Estimate = \\
\hline 3 & $\operatorname{PROF}\left(\mathrm{X}_{2}\right)$ & $-0,013$ & $-0,213$ & 0,832 & 0,0901432 \\
\hline 4 & $\operatorname{LEV}\left(\mathrm{X}_{3}\right)$ & $-0,042$ & $-1,395$ & 0,166 & F hitung $=6,993$ \\
\hline 5 & $\operatorname{MANJ}\left(\mathrm{X}_{4}\right)$ & $-0,003$ & $-2,269$ & 0,026 & F Sign $=0,000$ \\
\hline 6 & $\operatorname{KOM}\left(\mathrm{X}_{5}\right)$ & $-0,013$ & $-2,163$ & 0,033 & \\
\hline
\end{tabular}

From the test results above, a regression equation can be drawn up, as Following:

Csrd $=-0.567+0.072$ size -0.013 prof -0.042 lev -0.003 manj -0.013 kom + ei

1. The constant coefficient based on the regression results is -0.567 with a negative value, this means that the y value (csrd) will be -0.567 if the independent variables, namely size, profitability, leverage, management ownership, the size of the board of commissioners each have a value of 0 . With in other words, before there is the influence of size, profitability, leverage, management ownership, the size of the large commissioners csrd $=-0.567$.

2. The regression coefficient of 0.072 states that every addition of one unit of the size variable will also increase the csrd of 0.072 .

3 . The regression coefficient -0.013 states that every addition of one unit of the profitability variable will also reduce the csrd by -0.013 . 
4. The regression coefficient -0.042 states that every addition of one unit of the leverage variable will also reduce the csrd by -0.042 .

5. The regression coefficient -0.003 states that every addition of one unit of management ownership variable, it will also reduce csrd by -0.003 .

6. The regression coefficient -0.013 states that every addition of one unit of the size of the board of commissioners variables, it will also reduce the csrd by -0.013 .

4. Hypothesis Test

Testing of the hypothesis carried out in this study was carried out. In the following way:

\section{A. T test}

This test was conducted to see the significance of the regression coefficient for each of the independent variables of this study which consisted of size (x1), prof (x2), lev (x3), manj (x4), and kom (x5) on the dependent variable, namely $\operatorname{csrd}(\mathrm{y})$.

- The size regression coefficient has a tcount of 4,500 with a significance of 0,000 . Based on the results of the statistical calculation findings, it can be seen that the tcount of 4,500 is supported by a significance number of 0,000 (less than $\alpha=0.05$ ) so h0 is rejected or ha is accepted. So it can be concluded that size has a significant effect on corporate social responsibility disclosure.

- Profitability regression coefficient has a tcount of -0.213 with a significant 0.832. Based on the results of the statistical calculation findings, it can be seen that tcount of -0.213 is supported by a significant number of 0.832 (greater than $\alpha=0.05$ ), so h0 is accepted or ha is rejected. So it can be concluded that profitability has no significant effect on the corporate social responsibility disclosure.

- The leverage regression coefficient has a tcount of -1.395 with a significant 0.166. Based on the findings of these statistical calculations, it can be seen that the tcount of -1.395 is supported by a significant number of 0.166 (being greater than $\alpha=0.05$ ) then $\mathrm{h} 0$ is accepted or ha is rejected. So it can be concluded that leverage has no significant effect on corporate social responsibility disclosure.

- Management ownership regression coefficient has a tcount of -2.269 with a significant 0.026 . Based on the findings of these statistical calculations, it can be seen that the tcount of -2.269 is supported by a significant number of 0.026 (less than $\alpha=0.05$ ) then h0 is rejected or ha is accepted. . So it can be concluded that management ownership has a significant effect on corporate social responsibility disclosure.

- The regression coefficient for the size of the board of commissioners has a tcount of -2.163 with a significance of 0.033 . Received. So it can be concluded that the size of the board of commissioners has a significant 
effect on the corporate social responsibility disclosure.

\section{B. F test}

The simultaneous effect of the independent variables of this study consisting of size, profitability, leverage, management ownership, board size on the dependent variable, namely csrd, can be determined by performing the f test. From the results of the calculations shown in table 8 , it is known that fcount is obtained in numbers. 6,993 with sig 0,000 .

by using a significance level of $\alpha=0.05$, then h0 was successfully rejected and h1 was successfully accepted. the rejection of $\mathrm{h} 0$ is proven by the calculation result that the sig value of 0.00 is less than $\alpha=0.05$. so it can be concluded that from size (x1), prof (x2), lev (x3), manj (x4), and kom (x5) simultaneously have a significant influence on corporate social responsibility disclosure.

\section{Analysis of the coefficient of determination}

The coefficient of determination ( $\mathrm{r} 2$ ) in essence measures how far the model's ability to explain the variation in the dependent variable. the coefficient of determination is between zero and one. the small value of $r 2$ means that the ability of the independent variables to explain the variance of the dependent variables is very limited judging from table 8 above, the coefficient of determination (adjusted r2) is 0.229 or $22.9 \%$.

This means $22.9 \%$ csrd which can be explained by the variation of the five independent variables, namely the variable size, profitability, leverage, management ownership, the size of the board of commissioners. while the remaining $77.1 \%$ is explained by reasons other than regression. standard error of estimate (see) is 0.0901 . the smaller the see value will make the regression model more precise in predicting the dependent model.

\section{Conclusions}

Based on the results of statistical tests simultaneously and partially, the variable characteristics of the company on the corporate social responsibility disclosure (csrd) in indonesia using multiple regression analysis can be concluded as, Size is proven to have an effect on the corporate social responsibility disclosure (csrd) in the annual reports of manufacturing companies. Profitability is proven to have no effect on corporate social responsibility disclosure (csrd) in manufacturing company annual reports. Leverage is proven to have no effect on corporate social responsibility disclosure (csrd) in manufacturing company annual reports. Management ownership is proven to have an effect on corporate social responsibility disclosure (csrd) in the annual reports of manufacturing companies. The size of the board of commissioners is proven to have an effect on the corporate social responsibility disclosure (csrd) in the annual reports of manufacturing companies. Simultaneously, size, profitability, leverage, management ownership, and board size affect the corporate social responsibility disclosure (csrd) in the annual report of a manufacturing company. 


\section{BIBLIOGRAFI}

Clough, Yann, Barkmann, Jan, Juhrbandt, Jana, Kessler, Michael, Wanger, Thomas Cherico, Anshary, Alam, Buchori, Damayanti, Cicuzza, Daniele, Darras, Kevin, \& Putra, Dadang Dwi. (2011). Combining high biodiversity with high yields in tropical agroforests. Proceedings of the National Academy of Sciences, 108(20), 8311-8316.

Dewi, Ida Ayu Putu Oki Yacintya; Yasa, Gerianta Wirawan. (2018). Pengaruh Ukuran Perusahaan, Profitabilitas, Tipe Perusahaan dan Kinerja Lingkungan terhadap Environmental Disclosure. E-Jurnal Akuntansi, 23(2).

Fahmi, Irham. (2015). Pengantar Manajemen Keuangan; Teori dan soal jawab.

Hadi, Nor. (2011). Corporate Social Responsibility (CSR) Edisi 1. Jakarta: Graha Ilmu.

Hery. (2016). Analisis Laporan Keuangan. Jakarta: Grasindo.

Kasmir, Sharryn. (2016). The Mondragon cooperatives and global capitalism: A critical analysis. New Labor Forum, 25(1), 52-59. SAGE Publications Sage CA: Los Angeles, CA.

Laksmitaningrum, Chintya Fadila, \& Purwanto, Agus. (2013). Analisis Pengaruh Karakteristik Perusahaan, Ukuran Dewan Komisaris dan Struktur Kepemilikan Terhadap Pengungkapan CSR (Studi Empiris pada Perusahaan Manufaktur Yang Terdaftar Di Bursa Efek Indonesia Tahun 2009-2011). Fakultas Ekonomika dan Bisnis.

Mardiah, Ainul, Satriana, Dwi Puspita, \& Syahriati, Elida. (2017). Peranan dukungan sosial dalam mencegah kekerasan dalam pacaran: studi korelasi pada remaja di Jakarta. Jurnal Psikologi Ulayat: Indonesian Journal of Indigenous Psychology, 4(1), 29-42.

Njoku, Howard O., Agashi, Boniface E., \& Onyegegbu, Samuel O. (2017). A numerical study to predict the energy and exergy performances of a salinity gradient solar pond with thermal extraction. Solar Energy, 157, 744-761.

Octarina, Nisha, Majidah, Majidah, \& Muslih, Muhamad. (2018). Pengungkapan Corporate Social Responsibility: Ukuran Dan Pertumbuhan Perusahaan, Serta Risiko Keuangan. Jurnal Riset Akuntansi Kontemporer, 10(1), 34-41.

Prastowo, Joko. (2011). Corporate social Responsibility: kunci meraih kemuliaan Bisnis. Samudra Biru.

Respati, Rheza Dwi, \& Hadiprajitno, P. Basuki. (2015). Analisis Pengaruh Profitabilitas, Leverage, Ukuran perusahaan, Tipe Industri, dan Pengungkapan Media Terhadap Pengungkapan Corporate Social Responsibility (Studi Empiris pada Perusahaan Manufaktur yang Terdaftar di Bursa Efek Indonesia Tahun 2014). Fakultas Ekonomika dan Bisnis. 
Sofyan, Syafri Harahap. (2013). Analisis kritis atas laporan keuangan. Jakarta: PT Rajagrafindo Persada.

Sudana, Imade. (2011). Manajemen Keuangan Perusahaan: Teori \& Praktik.

Wilangga, Imelda Dharma, Saebani, Akhmad, \& Wijayanti, Aniek. (2020). Pengaruh Profitabilitas, Ukuran Perusahaan, dan Leverage Terhadap Pengungkapan Corporate Social Responsibility. Konferensi Riset Nasional Ekonomi, Manajemen, Dan Akuntansi I.

Wulandari, Anak Agung Ayu Intan, \& Sudana, I. Putu. (2018). Pengaruh Profitabilitas, Kepemilikan Asing, Kepemilikan Manajemen, dan Leverage Pada Intensitas Pengungkapan Corporate Social Responsibility. E-Jurnal Akuntansi, 22(2), 14451472.

Zulhaimi, Hanifa, \& Nuraprianti, Neng Riyanti. (2019). Pengaruh Profitabilitas, Ukuran Dewan Komisaris, dan Ukuran Perusahaan Terhadap Corporate Social Responsibility Disclosure. Jurnal Riset Akuntansi Dan Keuangan Vol, 7(3). 